eference

\title{
NBS
}

Publi -

cations

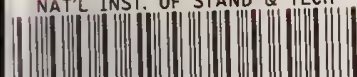

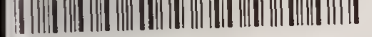

A I1105 97398

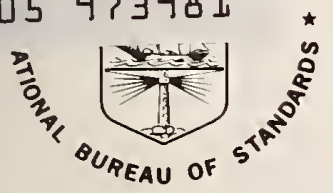

NBS TECHNICAL NOTE 1158

U.S. DEPARTMENT OF COMMERCE / National Bureau of Standards

\section{Accountability Tank Volume \\ Calibration Data}

$Q C \longrightarrow$

100

.45753

No. 1158

1982 


\section{NATIONAL BUREAU OF STANDARDS}

The National Bureau of Standards' was established by an act of Congress on March 3, 1901. The Bureau's overall goal is to strengthen and advance the Nation's science and technology and facilitate their effective application for public benelit. To this end, the Bureau conducts research and provides: (1) a basis for the Nation's physical measurement system, (2) scientific and technological services for industry and government, (3) a technical basis for equity in trade, and (4) technical services to promote public safety. The Bureau's technical work is performed by the National Measurement Laboratory, the National Engineering Laboratory, and the Institute for Computer Sciences and Technology.

THE NATIONAL MEASUREMENT LABORATORY provides the national system of physical and chemical and materials measurement; coordinates the system with measurement systems of other nations and furnishes essential services leading to accurate and uniform physical and chemical measurement throughout the Nation's scientific community, industry, and commerce; conducts materials research leading to improved methods of measurement, standards, and data on the properties of materials needed by industry, commerce, educational institutions, and Government; provides advisory and research services to other Government agencies; develops, produces, and distributes Standard Reference Materials; and provides calibration services. The Laboratory consists of the following centers:

\section{Absolute Physical Quantities ${ }^{2}$ - Radiation Research - Chemical Physics - Analytical Chemistry - Materials Science}

THE NATIONAL ENGINEERING LABORATORY provides technology and technical services to the public and private sectors to address national needs and to solve national problems; conducts research in engineering and applied science in support of these efforts; builds and maintains competence in the necessary disciplines required to carry out this research and technical service; develops engineering data and measurement capabilities; provides engineering measurement traceability services; develops test methods and proposes engineering standards and code changes; develops and proposes new engineering practices; and develops and improves mechanisms to transfer results of its research to the ultimate user. The Laboratory consists of the following centers:

\section{Applied Mathematics - Electronics and Electrical Engineering ${ }^{2}$ - Manufacturing Engineering - Building Technology - Fire Research - Chemical Engineering 2}

THE INSTITUTE FOR COMPUTER SCIENCES AND TECHNOLOGY conducts research and provides scientific and technical services to aid Federal agencies in the selection, acquisition, application, and use of computer technology to improve effectiveness and economy in Government operations in accordance with Public Law 89-306 (40 U.S.C. 759), relevant Executive Orders, and other directives; carries out this mission by managing the Federal Information Processing Standards Program, developing Federal ADP standards guidelines, and managing Federal participation in ADP voluntary standardization activities; provides scientific and technological advisory services and assistance to Federal agencies; and provides the technical foundation for computer-related policies of the Federal Government. The Institute consists of the following centers:

Programming Science and Technology-Computer Systems Engineering.

'Headquarters and Laboratories at Gaithersburg, MD, unless otherwise noted; mailing address Washington, DC 20234.

${ }^{2}$ Some divisions within the center are located at Boulder, CO 80303. 


\section{Accountability Tank Volume Calibration Data}

Frank E. Jones and John F. Houser

National Engineering Laboratory

Randall M. Schoonover

National Measurement Laboratory

National Bureau of Standards

Washington, DC 20234

Sponsored by:

U.S. Nuclear Regulatory Commission

7920 Norfolk Avenue

Bethesda, MD 20555

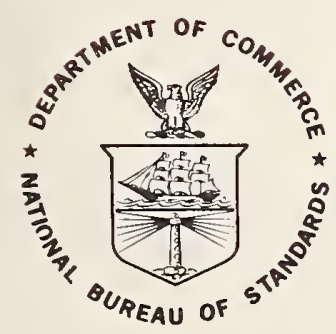

U.S. DEPARTMENT OF COMMERCE, Malcolm Baldrige, Secretary NATIONAL BUREAU OF STANDARDS, Ernest Ambler, Director 
The use of a company name in this publication does not constitute endorsement or recommendation by the National Bureau of Standards or any other agency of the Federal Government.

National Bureau of Standards Technical Note 1158

Nat. Bur. Stand. (U.S.), Tech. Note 1158,12 pages (Aug. 1982)

CODEN: NBTNAE

U.S. GOVERNMENT PRINTING OFFICE

WASHINGTON: 1982

For sale by the Superintendent of Documents, U.S. Government Printing Office, Washington, DC 20402 Price

(Add 25 percent for other than U.S. mailing) 
ACCOUNTABILITY TANK VOLUME CALIBRATION DATA

Frank E. Jones, John F. Houser, and Randa11 M. Schoonover
Nationa1 Bureau of Standards, Washington, DC 20234

This paper presents the very precise data from the volume calibration of a nuclear materials input accountability tank and briefly describes the treatment of the data. The calibration system involves the use of volumetric test measures for dispensing known increments of the calibration fluid (water) into the tank, and a nul1-operated quartz bourdon-type differential pressure gage for measuring the differential pressure between the bottom of the bubble on the tip of a "bubbler" tube near the bottom of the tank and a port in the top of the tank. The tank is essentially a right circular cylinder with a capacity of approximately 13,600 L $(3,600 \mathrm{gal})$. The height is approximately $3.4 \mathrm{~m}$ (11 ft) and the diameter is approximately $2.4 \mathrm{~m}$ ( $8 \mathrm{ft}$ ). The water volume and the differential pressure were adjusted to correspond to the reference temperature, $25.00{ }^{\circ} \mathrm{C}$.

Key words:Accountability tank; calibration; differential pressure; volume; volumetric test measures; water calibration.

\section{INTRODUCTION}

An earlier paper [1] described the application of a significantly improved system for the volume calibration of nuclear materials accountability tanks. The system involves the use of volumetric test measures for dispensing known increments of the calibration fluid (water) into the tank, and a null-operated quartz bourdon-type differential pressure gage for measuring the differential pressure between the bottom of the bubble [2] on the tip of a "bubbler" tube near the bottom of the tank and a port at the top of the tank. The system was used in a very successful calibration [1] of an input accountability tank at the Savannah River Plant in Aiken, South Carolina, operated for the U. S. Department of Energy by E. I. duPont de Nemours \& Co., Inc. It is the primary purpose of this paper to present the very precise data from this calibration and to briefly describe the treatment of the data. The tank volume calibration data have been used as an example in two different statistical papers on calibration $[3,4]$.

The input accountability tank that was calibrated at the Savannah River Plant is illustrated in figure 1 . It is essentially a right circular cylinder with a capacity of approximately $13,600 \mathrm{~L}(3,600 \mathrm{gal})$. The height is approximately $3.4 \mathrm{~m}$ (11

$\mathrm{ft}$ ) and the diameter is approximately $2.4 \mathrm{~m}(8 \mathrm{ft})$. The major details are shown in the figure. The cooling coils are of $51 \mathrm{~mm}$ (2 in) outside diameter and are located in the interior of the tank. The two "headers" are cylindrical, approximately $229 \mathrm{~mm}$ (9 in) long and $76 \mathrm{~mm}$ ( $3 \mathrm{in}$ ) in diameter. The tubing above the headers is approximately $76 \mathrm{~mm}$ (3 in) in outside diameter. 


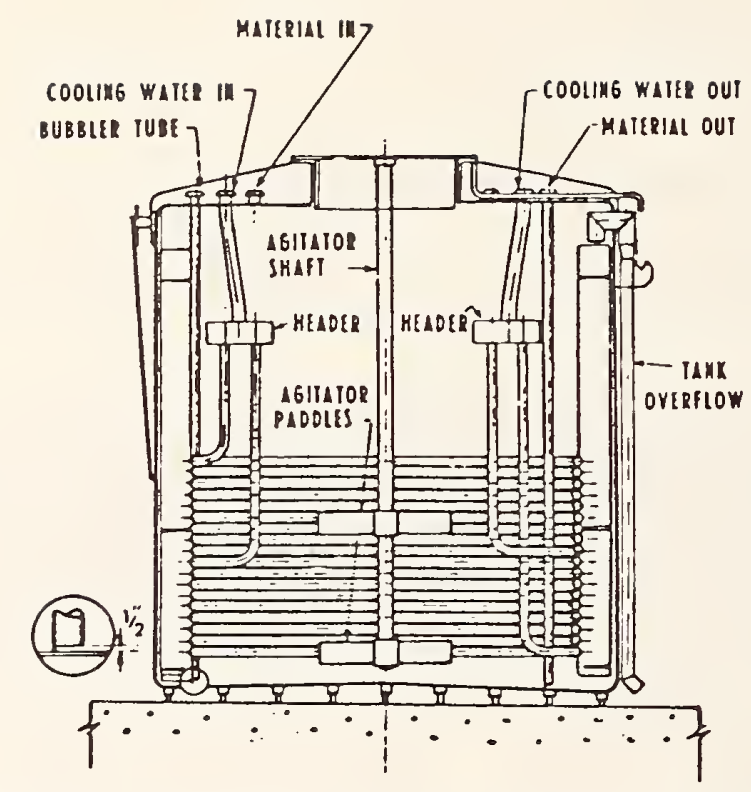

Figure 1. Sketch of an accountability tank.

\section{CALIBRATION RUNS}

Seven calibration runs were made, six in a "mock-up" area of the plant and one in the process location; the runs in the "mock-up" area were made prior to the installation of the tank in the process location in the canyon. The data for two of the runs (Runs 3 and 4) are not treated here due to operational problems which were analyzed and eliminated from subsequent runs [1].

In three runs (Runs 1, 5, and 7), 36 increments of water from a 378-L (100-ga1) volumetric test measure were introduced into the tank. In two runs (Runs 2 and 6), the first increment was introduced from a 189-L (50-ga1) test measure in order to offset the accumulated volume from Runs 1,5, and 7 by this amount. Subsequent increments in Runs 2 and 6 were of $378 \mathrm{~L}$ (100 ga1), except that 189-L (50-ga1) increments were used to arrive at the six check points, 1,890 (500), 5,300 (1,400), 8,330 (2, 200), $10,200(2,700), 12,100(3,200)$, and $13,600(3,600) \mathrm{L}$ (gal) that were used throughout the series of runs to establish control and to permit monitoring of the run-to-run performance of the calibration system.

In each of the calibration runs for each increment of water transferred to the tank from a volumetric test measure, the following were determined (after operation of the agitator) from instrument readings and instrument calibration data: temperature of the water in the test measure, temperature of the water in the tank, differential pressure, ambient air pressure, and ambient air relative humidity. The volume of water introduced in each transfer was determined from the calibration volume of the test measure, the test measure sight gage reading, and the temperature of the water in the test measure.

\section{TREATMENT OF THE DATA}

The calibration runs were made with water temperature in the vicinity of $22{ }^{\circ} \mathrm{C}$. The water volume, $V$, and differential pressure, $P$, were adjusted to correspond to the reference temperature, $25.00{ }^{\circ} \mathrm{C}$. V was adjusted using the relationship 


$$
\mathrm{V}_{25}=\mathrm{V}_{\mathrm{c}} \rho_{c} / \rho_{25}
$$

where $\mathrm{V}_{25}$ and $\mathrm{V}_{\mathrm{c}}$ are volume corresponding to the reference temperature and the calibration temperature, respectively; $\rho_{25}$ and $\rho_{c}$ are density of water at the reference temperature and the calibration temperature, respectively. The table of Wagenbreth and Blanke [5] was used to determine $\rho_{25}$ and $\rho_{c}$ for the temperatures.

The differential pressure, P, was adjusted [6] using the equation

$$
\mathrm{P}_{25}=\mathrm{P}_{\mathrm{C}}[1-2 \alpha(25.00-t)],
$$

where $\alpha$ is the coefficient of linear thermal expansion $q f$ the stainless steel of which the tank was fabricated (taken to $15.9 \times 10^{6}\left({ }^{\circ} \mathrm{C}\right)^{1}$ ), and $t$ is temperature in degrees Celsius.

The inside diameter of the connecting tubing used for the differential pressure measurement system installation in the "mock-up" area was smaller than that in the process location with resulting pressure drops which represented systematic errors in differential pressure. To estimate the magnitude of these systematic errors and to make corrections for them, the differential pressure in the "mock-up" area runs was interpolated using the equation

$$
\mathrm{P}_{\mathrm{I}}=\mathrm{P}_{25}+\left(\mathrm{V}_{7}-\mathrm{V}_{\mathrm{x}}\right)(\Delta \mathrm{P} / \Delta \mathrm{V})_{\mathrm{x}} \text {, }
$$

where $\mathrm{P}_{\mathrm{I}}$ is the interpolated differential pressure corresponding to $\mathrm{V}_{7}$, a value of volume in the process location run at the reference temperature, $V_{x}$ is a volume in a "mock-up" area run near $\mathrm{V}_{7}$, and $(\Delta \mathrm{P} / \Delta \mathrm{V})_{\mathrm{x}}$ is the "rate" of change of differential pressure with volume in the "mock-up" area run. The differences, $\left(\mathrm{P}_{\mathrm{I}}-\mathrm{P}_{7}\right)$, where $\mathrm{P}_{7}$ is the process location run differential pressure corresponding to $\mathrm{V}_{7}$, were computed. $\left(\mathrm{P}_{\mathrm{I}}-\mathrm{P}_{7}\right)$ was essentially constant for each run except for the first three points of each which were treated separately; therefore, the negative of the mean $\left(\mathrm{P}_{\mathrm{I}}-\mathrm{P}_{7}\right)$ was applied as a correction to each of the values of $\mathrm{P}_{25}$.

The temperature of the water in the tank, adjusted volume, and corrected differential pressure are tabulated in Tables 1-5. The transfer ${ }_{3}$ number refers to the increment of water dispensed into the tank, volume is given in $\mathrm{m}^{3}$ recalling that $1 \mathrm{~m}^{3}$ is equivalent to $1,000 \mathrm{~L}$.

\section{HEEL VOLUME}

The heel volume, the volume of water in the tank below the "bubbler" tip, was estimated by extrapolation from the first three points in Runs 1 and 3 and the first five points in Runs 2 and 6 . The mean of the four estimates is $101.4 \mathrm{~L}$ and the estimate of the standard deviation of the mean is $0.7 \mathrm{~L}$.

\section{ACKNOWLEDGMENTS}

The authors gratefully acknowledge the excellent cooperation and assistance of duPont and DOE personnel of the Savannah River Plant, the financial support provided by the U. S. Nuclear Regulatory Commission through the Office of Measurements for Nuclear Technology of the National Bureau of Standards, and the typing of the manuscript by Susan Johnson. 
Table 1. Calibration Data Adjusted to $25{ }^{\circ} \mathrm{C}$ for Run No. 1

\begin{tabular}{|c|c|c|c|}
\hline $\begin{array}{c}\text { Transfer } \\
\text { No. }\end{array}$ & $\begin{array}{l}\text { Water } \\
\text { Temp. } \\
\left({ }^{\circ} \mathrm{C}\right)\end{array}$ & $\begin{array}{c}\text { Volume } \\
\left(\mathrm{m}^{3}\right)\end{array}$ & $\begin{array}{l}\text { Diff. } \\
\text { Pressure } \\
\quad(\mathrm{Pa})\end{array}$ \\
\hline 1 & 22.31 & 0.37884 & 630.6 \\
\hline 2 & 22.41 & 0.75755 & 1473.1 \\
\hline 3 & 22.46 & 1.13642 & 2375.6 \\
\hline 4 & 22.46 & 1.51528 & 3263.5 \\
\hline 5 & 22.45 & 1.89414 & 4154.2 \\
\hline 6 & 22.50 & 2.27302 & 5044.9 \\
\hline 7 & 22.47 & 2.65191 & 5934.7 \\
\hline 8 & 22.48 & 3.03084 & 6820.2 \\
\hline 9 & 22.53 & 3.40977 & 7713.1 \\
\hline 10 & 22.51 & 3.78871 & 8603.8 \\
\hline 11 & 22.53 & 4.16762 & 9491.9 \\
\hline 12 & 22.54 & 4.54660 & 10383.8 \\
\hline 13 & 22.55 & 4.92553 & 11263.5 \\
\hline 14 & 22.57 & 5.30445 & 12143.8 \\
\hline 15 & 22.56 & 5.68339 & 12994.4 \\
\hline 16 & 22.58 & 6.06229 & 13816.8 \\
\hline 17 & 22.61 & 6.44116 & 14636.4 \\
\hline 18 & 22.62 & 6.82009 & 15449.8 \\
\hline 19 & 22.65 & 7.19901 & 16263.0 \\
\hline 20 & 22.82 & 7.57791 & 17078.4 \\
\hline 21 & 22.80 & 7.95687 & 17891.7 \\
\hline 22 & 22.77 & 8.33576 & 18703.9 \\
\hline 23 & 22.74 & 8.71469 & 19519.2 \\
\hline 24 & 22.68 & 9.09361 & 20334.8 \\
\hline 25 & 22.69 & 9.47253 & 21149.1 \\
\hline 26 & 22.64 & 9.85149 & 21963.7 \\
\hline 27 & 22.62 & 10.2305 & 22781.4 \\
\hline 28 & 22.61 & 10.6094 & 23597.1 \\
\hline 29 & 22.58 & 10.9883 & 24411.9 \\
\hline 30 & 22.58 & 11.3671 & 25226.9 \\
\hline 31 & 22.56 & 11.7459 & 26040.9 \\
\hline 32 & 22.54 & 12.1248 & 26855.2 \\
\hline 33 & 22.53 & 12.5037 & 27669.4 \\
\hline 34 & 22.53 & 12.8826 & 28486.4 \\
\hline 35 & 22.53 & 13.2616 & 29301.4 \\
\hline 36 & 22.51 & 13.6405 & 30116.1 \\
\hline
\end{tabular}


Table 2. Calibration Data Adjusted to $25{ }^{\circ} \mathrm{C}$ for Run No. 2

\begin{tabular}{|c|c|c|c|}
\hline $\begin{array}{c}\text { Transfer } \\
\text { No. }\end{array}$ & $\begin{array}{l}\text { Water } \\
\text { Temp. } \\
\left({ }^{\circ} \mathrm{C}\right)\end{array}$ & $\begin{array}{c}\text { Volume } \\
\left(\mathrm{m}^{3}\right)\end{array}$ & $\begin{array}{l}\text { Diff. } \\
\text { Pressure } \\
(\mathrm{Pa})\end{array}$ \\
\hline 1 & 22.65 & 0.18941 & 218.8 \\
\hline 2 & 22.14 & 0.56840 & 1039.2 \\
\hline 3 & 22.16 & 0.94740 & 1929.2 \\
\hline 4 & 22.13 & 1.32640 & 2819.5 \\
\hline 5 & 22.11 & 1.70525 & 3712.3 \\
\hline 6 & 22.15 & 1.89465 & 4152.8 \\
\hline 7 & 22.16 & 2.08411 & 4601.5 \\
\hline 8 & 22.16 & 2.46295 & 5489.8 \\
\hline 9 & 22.17 & 2.84196 & 6382.2 \\
\hline 10 & 22.18 & 3.22096 & 7269.4 \\
\hline 11 & 22.19 & 3.59999 & 8158.6 \\
\hline 12 & 22.20 & 3.97893 & 9052.0 \\
\hline 13 & 22.22 & 4.35796 & 9940.6 \\
\hline 14 & 22.22 & 4.73699 & 10825.1 \\
\hline 15 & 22.23 & 5.11598 & 11704.7 \\
\hline 16 & 22.26 & 5.30545 & 12145.2 \\
\hline 17 & 22.30 & 5.49482 & 12581.4 \\
\hline 18 & 22.32 & 5.87381 & 13407.2 \\
\hline 19 & 22.33 & 6.25282 & 14227.6 \\
\hline 20 & 22.34 & 6.63179 & 15045.3 \\
\hline 21 & 22.35 & 7.01070 & 15858.6 \\
\hline 22 & 22.36 & 7. 38969 & 16673.6 \\
\hline 23 & 22.38 & 7.76867 & 17487.7 \\
\hline 24 & 22.41 & 8.14760 & 18301.9 \\
\hline 25 & 22.43 & 8.33704 & 18709.4 \\
\hline 26 & 22.45 & 8.52645 & 19116.8 \\
\hline 27 & 22.48 & 8.90559 & 19931.7 \\
\hline 28 & 22.48 & 9.28455 & 20748.0 \\
\hline 29 & 22.48 & 9.66349 & 21561.4 \\
\hline 30 & 22.49 & 10.0425 & 22376.2 \\
\hline 31 & 22.50 & 10.2320 & 22786.5 \\
\hline 32 & 22.52 & 10.4214 & 23193.9 \\
\hline 33 & 22.56 & 10.8000 & 24008.1 \\
\hline 34 & 22.58 & 11.1788 & 24822.2 \\
\hline 35 & 22.59 & 11.5577 & 25635.7 \\
\hline 36 & 22.60 & 11.9366 & 26449.8 \\
\hline 37 & 22.61 & 12.1259 & 26856.5 \\
\hline 38 & 22.64 & 12.3153 & 27264.5 \\
\hline 39 & 22.64 & 12.6942 & 28078.6 \\
\hline 40 & 22.65 & 13.0731 & 28896.1 \\
\hline 41 & 22.66 & 13.4520 & 29709.5 \\
\hline 42 & 22.67 & 13.6414 & 30116.8 \\
\hline
\end{tabular}


Table 3. Calibration Data Adjusted to $25{ }^{\circ} \mathrm{C}$ for Run No. 5

\begin{tabular}{|c|c|c|c|}
\hline $\begin{array}{l}\text { Transfer } \\
\text { No. }\end{array}$ & $\begin{array}{l}\text { Water } \\
\text { Temp. } \\
\left({ }^{\circ} \mathrm{C}\right)\end{array}$ & $\begin{array}{c}\text { Volume } \\
\left(\mathrm{m}^{3}\right)\end{array}$ & $\begin{array}{l}\text { Diff. } \\
\text { Pressure } \\
\quad(\mathrm{Pa})\end{array}$ \\
\hline 1 & 22.13 & 0.37880 & 630.2 \\
\hline 2 & 22.23 & 0.75769 & 1473.4 \\
\hline 3 & 22.18 & 1.13665 & 2376.5 \\
\hline 4 & 22.13 & 1.51561 & 3267.4 \\
\hline 5 & 22.13 & 1.89458 & 4150.6 \\
\hline 6 & 22.09 & 2.27340 & 5044.4 \\
\hline 7 & 22.08 & 2.65216 & 5932.4 \\
\hline 8 & 22.08 & 3.03108 & 6819.3 \\
\hline 9 & 22.09 & 3.40994 & 7712.5 \\
\hline 10 & 22.10 & 3.78883 & 8602.9 \\
\hline 11 & 22.11 & 4.16781 & 9489.8 \\
\hline 12 & 22.10 & 4.54674 & 10382.6 \\
\hline 13 & 22.10 & 4.92572 & 11262.6 \\
\hline 14 & 22.12 & 5.30459 & 12142.0 \\
\hline 15 & 22.13 & 5.68354 & 12994.1 \\
\hline 16 & 22.12 & 6.06255 & 13817.3 \\
\hline 17 & 22.11 & 6.44156 & 14635.6 \\
\hline 18 & 22.10 & 6.82043 & 15450.1 \\
\hline 19 & 22.14 & 7.19940 & 16265.8 \\
\hline 20 & 22.14 & 7.57833 & 17081.0 \\
\hline 21 & 22.13 & 7.95726 & 17894.5 \\
\hline 22 & 22.13 & 8.33617 & 18707.3 \\
\hline 23 & 22.16 & 8.71507 & 19521.2 \\
\hline 24 & 22.13 & 9.09402 & 20340.5 \\
\hline 25 & 22.14 & 9.47292 & 21154.1 \\
\hline 26 & 22.14 & 9.85184 & 21968.3 \\
\hline 27 & 22.14 & 10.2308 & 22785.2 \\
\hline 28 & 22.14 & 10.6098 & 23600.1 \\
\hline 29 & 22.14 & 10.9887 & 24413.6 \\
\hline 30 & 22.14 & 11.3676 & 25227.5 \\
\hline 31 & 22.14 & 11.7466 & 26042.0 \\
\hline 32 & 22.14 & 12.1255 & 26853.8 \\
\hline 33 & 22.13 & 12.5044 & 27669.4 \\
\hline 34 & 22.12 & 12.8834 & 28486.4 \\
\hline 35 & 22.14 & 13.2623 & 29300.9 \\
\hline 36 & 22.11 & 13.6413 & 30115.4 \\
\hline
\end{tabular}


Table 4. Calibration Data Adjusted to $25{ }^{\circ} \mathrm{C}$ for Run No. 6

\begin{tabular}{|c|c|c|c|}
\hline $\begin{array}{c}\text { Transfer } \\
\text { No. }\end{array}$ & $\begin{array}{l}\text { Water } \\
\text { Temp. } \\
\left({ }^{\circ} \mathrm{C}\right)\end{array}$ & $\begin{array}{c}\text { Volume } \\
\left(\mathrm{m}^{3}\right)\end{array}$ & $\begin{array}{l}\text { Diff. } \\
\text { Pressure } \\
\quad(\mathrm{Pa})\end{array}$ \\
\hline 1 & 21.53 & 0.18949 & 220.5 \\
\hline 2 & 21.23 & 0.56843 & 1040.2 \\
\hline 3 & 21.24 & 0.94746 & 1930.2 \\
\hline 4 & 21.27 & 1.32640 & 2816.5 \\
\hline 5 & 21.26 & 1.70527 & 3713.4 \\
\hline 6 & 21.27 & 1.89466 & 4156.0 \\
\hline 7 & 21.27 & 2.08406 & 4602.4 \\
\hline 8 & 21.25 & 2.46313 & 5490.4 \\
\hline 9 & 21.24 & 2.84205 & 6384.2 \\
\hline 10 & 21.22 & 3.22114 & 7272.1 \\
\hline 11 & 21.21 & 3.60028 & 8162.5 \\
\hline 12 & 21.21 & 3.97932 & 9052.8 \\
\hline 13 & 21.24 & 4.35825 & 9943.2 \\
\hline 14 & 21.25 & 4.73715 & 10827.7 \\
\hline 15 & 21.26 & 5.11601 & 11706.3 \\
\hline 16 & 21.28 & 5.30558 & 12146.5 \\
\hline 17 & 21.28 & 5.49499 & 12582.9 \\
\hline 18 & 21.28 & 5.87408 & 13409.2 \\
\hline 19 & 21.28 & 6.25317 & 14227.8 \\
\hline 20 & 21.28 & 6.63211 & 15043.4 \\
\hline 21 & 21.27 & 7.01115 & 15858.9 \\
\hline 22 & 21.26 & 7.39017 & 16673.1 \\
\hline 23 & 21.26 & 7.76916 & 17487.4 \\
\hline 24 & 21.25 & 8.14815 & 18301.8 \\
\hline 25 & 21.26 & 8.33774 & 18706.8 \\
\hline 26 & 21.26 & 8.52723 & 19115.3 \\
\hline 27 & 21.26 & 8.90621 & 19929.2 \\
\hline 28 & 21.25 & 9.28520 & 20745.0 \\
\hline 29 & 21.24 & 9.66418 & 21559.9 \\
\hline 30 & 21.23 & 10.0431 & 22374.1 \\
\hline 31 & 21.23 & 10.2326 & 22783.9 \\
\hline 32 & 21.23 & 10.4220 & 23195.2 \\
\hline 33 & 21.23 & 10.8010 & 24008.3 \\
\hline 34 & 21.24 & 11.1800 & 24823.2 \\
\hline 35 & 21.24 & 11.5590 & 25638.7 \\
\hline 36 & 21.23 & 11.9379 & 26453.6 \\
\hline 37 & 21.23 & 12.1274 & 26859.3 \\
\hline 38 & 21.24 & 12.3169 & 27268.5 \\
\hline 39 & 21.24 & 12.6959 & 28083.7 \\
\hline 40 & 21.24 & 13.0749 & 28900.3 \\
\hline 41 & 21.23 & 13.4538 & 29715.5 \\
\hline 42 & 21.24 & 13.6433 & 30122.6 \\
\hline
\end{tabular}


Table 5. Calibration Data Adjusted to $25{ }^{\circ} \mathrm{C}$ for Run No. 7

\begin{tabular}{|c|c|c|c|}
\hline $\begin{array}{l}\text { Transfer } \\
\text { No. }\end{array}$ & $\begin{array}{l}\text { Water } \\
\text { Temp. } \\
\left({ }^{\circ} \mathrm{C}\right)\end{array}$ & $\begin{array}{c}\text { Volume } \\
\left(\mathrm{m}^{3}\right)\end{array}$ & $\begin{array}{l}\text { Diff } \\
\text { Pressure } \\
\quad(\mathrm{Pa})\end{array}$ \\
\hline 1 & 22.03 & 0.37884 & 629.2 \\
\hline 2 & 22.85 & 0.75767 & 1474.9 \\
\hline 3 & 22.74 & 1.13646 & 2375.7 \\
\hline 4 & 22.89 & 1.51523 & 3265.2 \\
\hline 5 & 22.97 & 1.89401 & 4154.3 \\
\hline 6 & 23.03 & 2.27272 & 5046.5 \\
\hline 7 & 23.09 & 2.65154 & 5933.9 \\
\hline 8 & 23.10 & 3.03029 & 6820.6 \\
\hline 9 & 23.09 & 3.40919 & 7712.8 \\
\hline 10 & 23.08 & 3.78805 & 8601.3 \\
\hline 11 & 23.08 & 4.16693 & 9486.7 \\
\hline 12 & 23.08 & 4.54579 & 10381.9 \\
\hline 13 & 23.07 & 4.92470 & 11260.3 \\
\hline 14 & 23.08 & 5.30359 & 12140.5 \\
\hline 15 & 23.08 & 5.68248 & 12993.4 \\
\hline 16 & 23.06 & 6.06140 & 13815.6 \\
\hline 17 & 23.05 & 6.44025 & 14634.4 \\
\hline 18 & 23.07 & 6.81913 & 15448.7 \\
\hline 19 & 23.05 & 7.19798 & 16262.0 \\
\hline 20 & 23.05 & 7.57684 & 17076.0 \\
\hline 21 & 23.06 & 7.95565 & 17889.6 \\
\hline 22 & 23.06 & 8.33453 & 18703.2 \\
\hline 23 & 23.07 & 8.71340 & 19517.2 \\
\hline 24 & 23.07 & 9.09241 & 20332.8 \\
\hline 25 & 23.06 & 9.47135 & 21147.8 \\
\hline 26 & 23.06 & 9.85020 & 21961.1 \\
\hline 27 & 23.06 & 10.2291 & 22777.5 \\
\hline 28 & 23.06 & 10.6079 & 23594.5 \\
\hline 29 & 23.07 & 10.9868 & 24408.8 \\
\hline 30 & 23.07 & 11.3656 & 25223.8 \\
\hline 31 & 23.06 & 11.7445 & 26036.0 \\
\hline 32 & 23.06 & 12.1234 & 26850.7 \\
\hline 33 & 23.06 & 12.5024 & 27665.7 \\
\hline 34 & 23.07 & 12.8813 & 28482.1 \\
\hline 35 & 23.07 & 13.2602 & 29296.7 \\
\hline 36 & 23.07 & 13.6391 & 30110.7 \\
\hline
\end{tabular}


6. REFERENCES

[1] Jones, F. E., Application of an improved volume calibration system to the calibration of accountability tanks. Nuclear Safeguards Technology 1978, Vo1. II. International Atomic Energy Agency (Vienna), 1979, 653-659.

[2] Gaigalas, A. K.; and Robertson, B. Time dependence of pressure in a bubbler tube, submitted to AIChE Journal (Feb. 1981).

[3] Lechner, J. A.; Reeve, C. P.; and Spiegelman, C. H. A new method of assigning uncertainty in volume calibration. Nat. Bur. Stand. (U.S.) NBSIR 80-2151, 1980 December.

[4] Sacks, J.; and Spiegelman, C. H. Nonparametric calibration, submitted to Technometrics.

[5] Wagenbreth, H.; and Blanke, W. PTB-Mitt., 81, S. 412-415; 1971.

[6] Jones, F. E. A Tank Volume Calibration Algorithm, undergoing editorial review. 
BIBLIOGRAPHIC DATA

SHEET (See instructions)

1. PUBLICATION OR REPORT NO. NBS TN 1158
2. Performing Organ. Report Nod 3. Publication Date

August 1982

4. TITLE AND SUBTITLE

Accountability Tank Volume Calibration Data

5. AUTHOR(S)

Frank E. Jones, John F. Houser, Randal1 M. Schoonover

6. PERFORMING ORGANIZATION (If joint or other than NBS, see instructions)

7. Contract/Grant No.

NATIONAL BUREAU OF STANDARDS

DEPARTMENT OF COMMERCE

WASHINGTON, D.C. 20234

8. Type of Report \& Period Covered

9. SPONSORING ORGANIZATION NAME AND COMPLETE ADDRESS (Street, City, State, ZIP)

Fina1

U.S. Nuclear Regulatory Commission

7920 Norfolk Ave.

Bethesda, MD 20555

10. SUPPLEMENTARY NOTES

[ Document describes a computer program; SF-185, FIPS Software Summary, is attached.

11. ABSTRACT (A 200-word or less factual summary of most significant information. If document includes a significant bibliography or literature survey. mention it here)

This paper presents the very precise data from the volume calibration of a nuclear materials input accountability tank and briefly describes the treatment of the data. The calibration system involves the use of volumetric test measures for dispensing known increments of the calibration fluid (water) into the tank, and a null-operated quartz bourdon-type differential pressure gage for measuring the differential pressure between the bottom of the bubble on the tip of a "bubbler" tube near the bottom of the tank and a port in the top of the tank. The tank is essentially a right circular cylinder with a capacity of approximately $13,600 \mathrm{~L}(3,600 \mathrm{gal})$. The height is approximately $3.4 \mathrm{~m}$ (11 ft) and the diameter is approximately $2.4 \mathrm{~m}(8 \mathrm{ft})$. The water volume and the differential pressure were adjusted to correspond to the reference temperature, $25.00{ }^{\circ} \mathrm{C}$.

12. KEY WORDS (Six to twelve entries; alphabetical order; capitalize only proper names; and separate key words by semicolons)

Accountability tank; calibration; differential pressure; volume; volumetric test measures; water calibration.

\section{AVAILABILITY}

[X] Unlimited

$\square$ For Official Distribution. Do Not Release to NTIS

$\mathrm{X}$ Order From Superintendent of Documents, U.S. Government Printing Office, Washington, D.C. 20402.
14. NO. OF

PRINTED PAGES

$$
12
$$

15. Price

Order From National Technical Information Service (NTIS), Springfield, VA. 2216I 


\section{NBS TECHNICAL PUBLICATIONS}

\section{PERIODICALS}

JOURNAL OF RESEARCH-The Journal of Research of the National Bureau of Standards reports NBS research and development in those disciplines of the physical and engineering sciences in which the Bureau is active. These include physics, chemistry, engineering, mathematics, and computer sciences. Papers cover a broad range of subjects, with major emphasis on measurement methodology and the basic technology underlying standardization. Also included from time to time are survey articles on topics closely related to the Bureau's technical and scientific programs. As a special service to subscribers each issue contains complete citations to all recent Bureau publications in both NBS and nonNBS media. Issued six times a year. Annual subscription: domestic $\$ 18$; foreign $\$ 22.50$. Single copy, $\$ 4.25$ domestic; $\$ 5.35$ foreign.

\section{NONPERIODICALS}

Monographs-Major contributions to the technical literature on various subjects related to the Bureau's scientific and technical activities.

Handbooks-Recommended codes of engineering and industrial practice (including safety codes) developed in cooperation with interested industries, professional organizations, and regulatory bodies.

Special Publications-Include proceedings of conferences sponsored by NBS, NBS annual reports, and other special publications appropriate to this grouping such as wall charts, pocket cards, and bibliographies.

Applied Mathematics Series-Mathematical tables, manuals, and studies of special interest to physicists, engineers, chemists, biologists, mathematicians, computer programmers, and others engaged in scientific and technical work.

National Standard Reference Data Series-Provides quantitative data on the physical and chemical properties of materials, compiled from the world's literature and critically evaluated. Developed under a worldwide program coordinated by NBS under the authority of the National Standard Data Act (Public Law 90-396).

NOTE: The principal publication outlet for the foregoing data is the Journal of Physical and Chemical Reference Data (JPCRD) published quarterly for NBS by the American Chemical Society (ACS) and the American Institute of Physics (AIP). Subscriptions, reprints, and supplements available from ACS, 1155 Sixteenth St, NW, Washington, DC 20056
Building Science Series-Disseminates technical information developed at the Bureau on building materials, components, systems, and whole structures. The series presents research results, test methods, and performance criteria related to the structural and environmental functions and the durability and safety characteristics of building elements and systems.

Technical Notes-Studies or reports which are complete in themselves but restrictive in their treatment of a subject. Analogous to monographs but not so comprehensive in scope or definitive in treatment of the subject area. Often serve as a vehicle for final reports of work performed at NBS under the sponsorship of other government agencies.

Voluntary Product Standards-Developed under procedures published by the Department of Commerce in Part 10. Title 15, of the Code of Federal Regulations. The standards establish nationally recognized requirements for products, and provide all concerned interests with a basis for common understanding of the characteristics of the products. NBS administers this program as a supplement to the activities of the private sector standardizing organizations

Consumer Information Series-Practical information, based on NBS research and experience, covering areas of interest to the consumer. Easily understandable language and illustrations provide useful background knowledge for shopping in today's technological marketplace.

Order the above NBS publications from: Superintendent of Documents. Government Printing Office, Washington. DC 20402

Order the following NBS publications-FIPS and NBSIR's-from the National Technical Information Services, Springfield, VA 22161.

Federal Information Processing Standards Publications (FIPS PUB)-Publications in this series collectively constitute the Federal Information Processing Standards Register. The Register serves as the official source of information in the Federal Government regarding standards issued by NBS pursuant to the Federal Property and Administrative Services Act of 1949 as amended, Public Law 89-306 (79 Stat. 1127), and as implemented by Executive Order 11717 (38 FR 12315, dated May 11, 1973) and Part 6 of Title 15 CFR (Code of Federal Regulations).

NBS Interagency Reports (NBSIR) - A special series of interim or final reports on work performed by NBS for outside sponsors (both government and non-government). In general, initial distribution is handled by the sponsor; public distribution is by the National Technical Information Services, Springfield, VA 22161 , in paper copy or microfiche form. 
U.S. DEPARTMENT OF COMMERCE

National Bureau of Standards

Weshington. DC 20234

PDSTAGE AND FEES PAID

COMMERCE CDM-215

\section{DFFICIAL BUSINESS}

Penalty for Private Use, $\$ 300$ 